\title{
Balearic Islands vs Algeria: two nearby western Mediterranean elasmobranch assemblages with different oceanographic scenarios and fishing histories
}

\author{
FRANCESC ORDINES ${ }^{1}$, ENRIC MASSUTÍ ${ }^{1}$, JOAN MORANTA ${ }^{1}$, \\ ANTONI QUETGLAS ${ }^{1}$, BEATRIZ GUIJARRO ${ }^{1}$ and KHALED FLITI ${ }^{2}$ \\ ${ }^{1}$ Instituto Español de Oceanografía, Centre Oceanogràfic de les Balears, Moll de Ponent s/n, 07015 Palma, Spain. \\ E-mail: xisco.ordinas@ba.ieo.es \\ ${ }^{2}$ Ministère de la Pêche et des Resources Halieutiques, Rue des Canons, 16000 Algiers, Algeria.
}

SUMMARY: In this paper we compare the elasmobranch composition, depth-related trends of species and community descriptors (abundance, biomass, mean fish weight, species richness and diversity) of the Balearic Islands Archipelago and Algeria (north- and southwestern Mediterranean, respectively). The samples used in this study were collected in bottom trawl surveys between 36 and $779 \mathrm{~m}$ depth. Generalized linear models, linear regression, cluster and similarity percentage analyses, and generalized additive models were used to compare the two areas. Twenty-nine elasmobranch species were caught, 12 of them common to both areas, 7 appearing only in the Balearic Islands, and 10 only in Algeria. The bathymetric distributions of species were, in most cases, best fitted to uni-modal response curves. The models for species common to both areas showed similar bathymetric trends, except for Etmopterus spinax, which in Algeria showed a maximum abundance located $154 \mathrm{~m}$ shallower than in the Balearic Islands. Four bathymetric assemblages were identified in both areas with similar depth ranges but with different species composition. The mean values of the community descriptors were higher on the shelf in the Balearic Islands, whereas higher values were detected on the slope in Algeria. Different between-area bathymetric trends for all the descriptors were detected, with the exception of mean fish weight. The distinct environmental scenarios and fishing histories of the areas studied are discussed as underlying traits influencing the elasmobranch populations.

Keywords: community descriptors, bathymetric trends, environmental factors, fishing mortality, threatened species.

RESUMEN: ISLAS BALEARES VS ARGELIA: DOS POBLACIONES CERCANAS DE ELASMOBRANQUIOS EN EL MEDITERRÁNEO OCCIDENTAL CON DISTINTAS CONDICIONES OCEANOGRÁFICAS E HISTORIAS PESQUERAS. - Este artículo compara la composición específica de elasmobranquios, su tendencia batimétrica, e indicadores de comunidad (abundancia, biomasa, peso medio individual, riqueza específica y diversidad) del archipiélago de las Islas Baleares y Argelia (Mediterráneo nor- y sur-occidental, respectivamente). Las muestras utilizadas se recogieron en campañas de arrastre entre 36-779 m de profundidad. Para comparar las dos áreas se utilizaron modelos lineales generalizados, regresión lineal, análisis de cluster y de porcentaje de similitud, y modelos aditivos generalizados. Se capturaron 29 especies de elasmobranquios; 12 fueron comunes a ambas áreas, 7 aparecieron sólo en las Balears, y 10 sólo en Argelia. En general, la distribución batimétrica de las especies se ajustó mejor a una curva de respuesta unimodal. Las especies comunes a ambas áreas mostraron tendencias batimétricas similares, excepto Etmopterus spinax que en Argelia mostró un máximo de abundancia localizado $154 \mathrm{~m}$ por encima del registrado en el Archipiélago. Se identificaron 4 comunidades batimétricas en ambas áreas con rangos de profundidad similares, pero con distinta composición específica. Los valores medios de los indicadores de comunidad fueron más altos en la plataforma continental del Archipiélago, mientras que en el talud fueron superiores en Argelia. A excepción del peso medio individual, los demás indicadores mostraron distintas tendencias batimétricas dependiendo del área. Las diferencias en condiciones ambientales e historias pesqueras son discutidas como características subyacentes que influyen en las poblaciones de elasmobranquios.

Palabras clave: indicadores de comunidad, tendencias batimétricas, factores ambientales, mortalidad por pesca, especies amenazadas. 


\section{INTRODUCTION}

The elasmobranchs are considered especially vulnerable to the impact of fishing activities because of their k-selected life-history strategy, characterized by slow growth, late attainment of sexual maturity, long life spans and low fecundity (Stevens et al., 2000). Although these characteristics make these species very different from teleosts, it is still difficult to find references specifically addressed to the elasmobranch communities in the Mediterranean. With some exceptions (e.g. Capapé et al., 2000; Relini et al., 2000; Bertrand et al., 2000; Massutí and Moranta, 2003), most studies in which they appear are addressed to fish communities in general, elasmobranchs having low weight in the analyses and results because of the general overwhelming higher abundance of teleosts. However, "traditional" community descriptors such as abundance, biomass, mean fish weight, species richness and diversity of elasmobranchs could be a useful tool for detecting fishing impacts on fish communities, because these species are likely to be the first to decline from fishing (Stevens et al., 2000) because of their higher vulnerability (relative to teleosts), even when subjected to low levels of fishing pressure.

The Balearic Islands Archipelago (northwestern Mediterranean) and Algeria (southwestern Mediterranean) are separated by around 130 nautical miles. The Algerian coast is mainly influenced by the inflow of Atlantic water which enters the Mediterranean and moves eastward, forming the Algerian current (Benzhora and Millot, 1995; Millot, 1999). The Balearic Islands can also be influenced by these Atlantic waters in the south, but in the north it is mainly influenced by Mediterranean waters on their way back to the Gibraltar Strait (Northern and Balearic currents on the peninsular and insular coasts; Pinot et al., 2002; Monserrat et al., 2008).

There are also differences between the types of sediment on the continental shelf of the two areas. The absence of rivers in the Balearic Islands reduces the amount of terrigenous and relatively mobile sediments, most muddy bottoms being of biogenic origin (Canals and Ballesteros, 1997). The sediments of the Balearic shelf are mainly gravels or coarse sands, with a high percentage of carbonates (Fornós et al., 1988, Acosta et al., 2002). Within the general oligotrophic environment of the Mediterranean, the waters around the Balearic Islands, where there is no supply of nutrients from land runoff, show more pronounced oligotrophy than the adjacent waters off the Iberian coast and the Gulf of Lions (Estrada, 1996). This oligotrophy increases the clarity of waters in the Balearic Islands, which allows the development of red algae communities down to 90-100 m depth (Ballesteros, 1994). The algal gravel facies, mainly formed by red algae fragments $(60 \%$ of the sediments), is the characteristic type of bottom of the Balearic shelf from 40 to $90 \mathrm{~m}$ depth (Fornós et al., 1988). On the other hand, the presence of rivers in- creases the supply of terrigenous sediments in Algeria. In this area, although algal facies such as Corallinacea beds also occur, muddy bottoms are widely distributed on the continental shelf at the shallowest depths, and even reach the littoral coast (Le Danois et al., 1924; Maurin, 1968; Bakalem et al., 1981).

In the Balearic Islands, the deep-water fishery targeting red shrimp (Aristeus antennatus) has a long history, starting in the late 1940s and showing an increasing fishing effort down to $800 \mathrm{~m}$ depth during the last few decades (Carbonell and Azevedo, 2003). By contrast, according to the FAO, the most important fishing activity in Algeria targets small pelagic species. Moreover, the geo-morphological characteristics of the Algerian shelf have not facilitated the development of a demersal trawl fishery (it is estimated that only $1 / 3$ of the continental shelf is suitable for trawling), which at the beginning of the last decade was mainly performed with small boats fishing down to $400 \mathrm{~m}$ depth (GFCM, 1980, Nouar, 2001, Mouffok et al., 2008).

The present paper aims to evaluate elasmobranch assemblages on the circa-littoral soft bottoms exploited by the bottom trawl fishery off the Balearic Islands and Algeria, two nearby areas with different oceanographic scenarios and fishing histories. To this end, depthrelated trends for species-specific densities, traditional community descriptors (i.e. density, mean fish weight, species richness and diversity) and assemblage composition are compared.

\section{MATERIALS AND METHODS}

\section{Sampling}

The samples used in the present study were collected in bottom-trawl surveys. The sampling scheme and gear (GOC-73) were the same in both the Balearic Islands and Algeria, and followed the protocol generally used throughout the Mediterranean in bottom-trawl surveys (MEDITS programme; Bertrand et al., 2002). In the case of the Balearic Islands, there is a ten-year series of BALAR-MEDITS annual bottom trawl surveys, beginning in 2001 (2001-2006 and 2007-2010 for BALAR and MEDITS surveys, respectively) and mainly carried out in spring and early summer. However, in order to avoid seasonal differences with the samples carried out off Algeria, we only used the BALAR 2001 and 2004 surveys, which were carried out in April and Aprilearly May, respectively. These surveys accounted for a total of 104 hauls between 45 and $753 \mathrm{~m}$ depth (Fig. 1). In the case of Algeria, samples were collected during two surveys carried out in 2003 and 2004 in March and February-early March, respectively. These surveys accounted for a total of 170 hauls between 45 and 779 $\mathrm{m}$ depth (Fig. 1). Table 1 shows the number of hauls in each of the depth strata considered in the sampling design in both areas. The scientific crew in charge of the species identification was the same for all surveys carried out in both areas. 


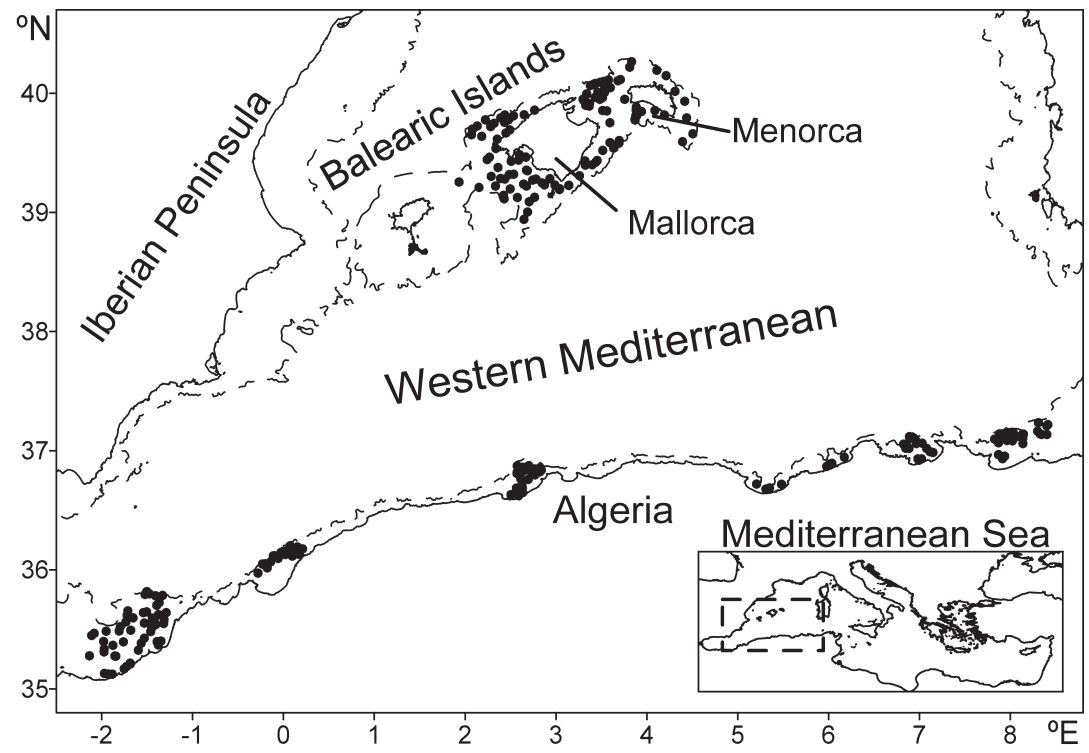

FIG. 1. - Map of the areas studied. Black dots represent the location of the samples collected. The $800 \mathrm{~m}$ isobath is also shown.

For the two areas surveyed hauls were conducted during daylight hours, and the mean towing speed was around 3 knots. The duration of hauls was 30 and 60 minutes for those carried out on the shelf $(<200 \mathrm{~m}$ depth) and the slope (>200 $\mathrm{m}$ depth), respectively. Depth was recorded every five minutes, and these records were used to calculate a mean depth value for each haul. The arrival and departure of the net to the bottom, in addition to its horizontal and vertical openings (on average, 16.4 and $2.8 \mathrm{~m}$, respectively), were measured using a SCANMAR system.

During the surveys, catch was sorted and individuals of each species were counted, weighed and measured. The data collected were standardized to one square kilometre. For both biomass and abundance, a data matrix was created, containing data of each species and the mean depth per haul.

\section{Bathymetric distribution of species}

Bathymetric distribution models were carried out for species appearing in at least 10 hauls in each area. Since it has been observed that species typically show uni-modal (bell-shaped) response curves with respect to environmental variables (i.e. Whittaker, 1956), the generalized linear model (GLM) and linear regression were applied to model the species response curves along the depth gradient. The response type (uni-modal

TABLE 1. - Number of hauls in each of the depth strata considered in the sampling design in both areas.

\begin{tabular}{lcc}
\hline Depth strata $(\mathrm{m})$ & \multicolumn{2}{c}{ Number of hauls } \\
& Balearic Islands & Algeria \\
\hline $45-100$ & 35 & 19 \\
$100-200$ & 30 & 18 \\
$200-500$ & 18 & 58 \\
$500-800$ & 21 & 46 \\
\hline
\end{tabular}

or linear) of a particular species was chosen on the basis of the lowest value of the Akaike information criterion as a measure of the parsimony of each regression model (Ter Braak and Smilauer, 2002).

The GLM used was a log-linear model, in which the linear predictor is a quadratic polynomial of the environmental variable. This model is precisely the "Gaussian" response curve that has been put forward as an ideal for species responses along an environmental gradient (Ter Braak, 1986). The data used for this analysis were the abundance of each species and the mean depth per haul.

\section{Assemblages and community descriptors}

The abundance data were subjected to cluster analysis in order to characterize the assemblages of each area. Due to the low frequency of appearance of most species, samples were pooled every $15 \mathrm{~m}$ of depth. In the resulting data matrix, the value of each cell corresponded to the average value of abundance of a particular species in hauls corresponding to the particular depth interval. In order to avoid the problems of dealing with an excessive number of zero values, the species appearing in less than $1 \%$ of hauls were omitted (5 and 6 species in the Balearic Islands and Algeria respectively; see Table 2). Data were squareroot transformed and the Bray-Curtis index was used as a between-haul similarity measure. The unweighted pair-group method with arithmetic mean was applied to link samples into clusters. Similarity percentage analysis (SIMPER) was used to assess species contribution to the detected assemblage. Analysis of similarity (ANOSIM) was used to test for differences between areas and by assemblage.

The following community descriptors were calculated: total abundance (ind. $\mathrm{km}^{-2}$ ), total biomass $(\mathrm{kg}$ 


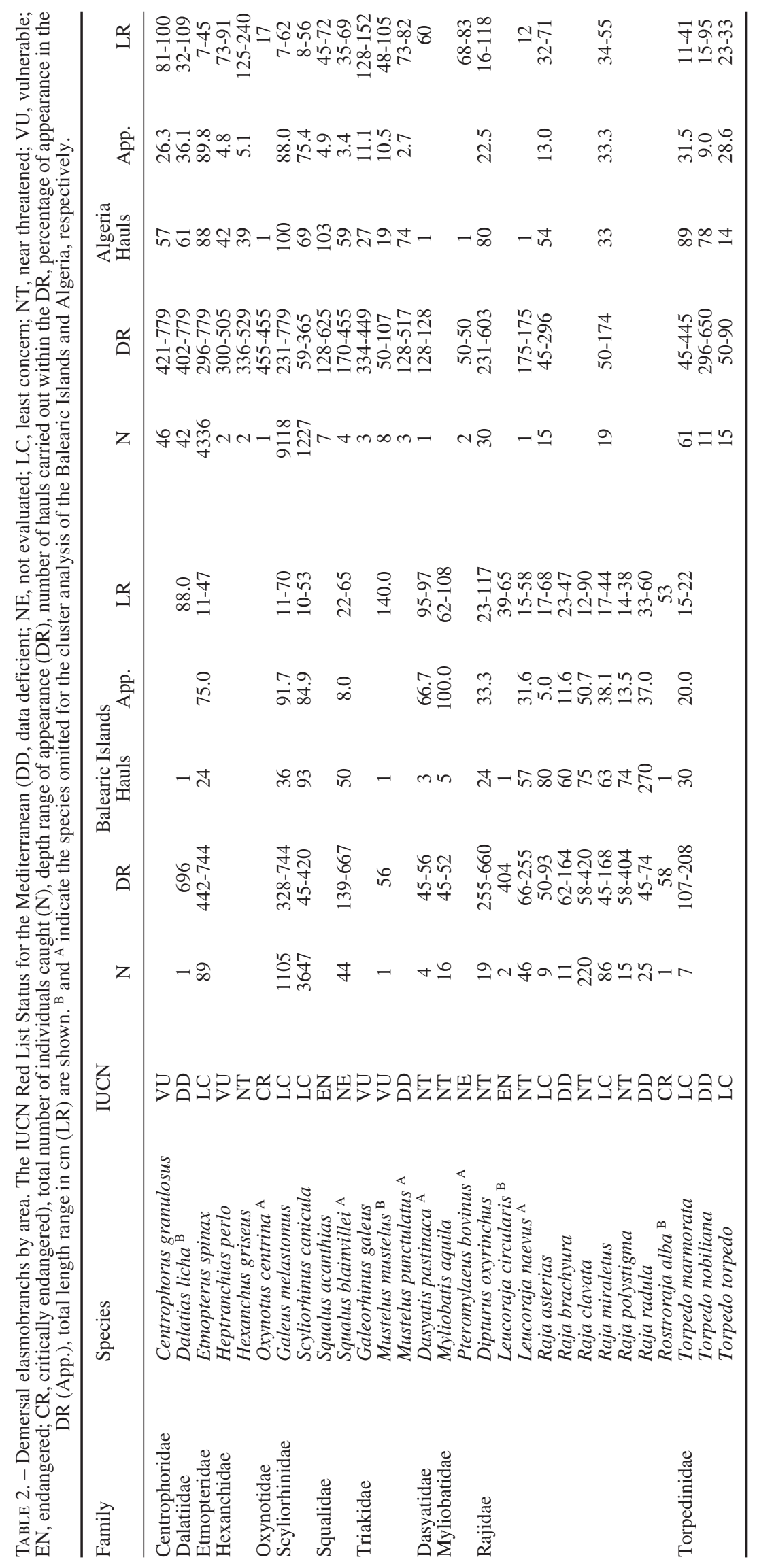


$\mathrm{km}^{-2}$ ), mean fish weight (MFW; $\mathrm{g}$ ), species richness $(\mathrm{S})$, and the Shannon diversity index ( $\left.\mathrm{H}^{\prime}\right)$. As mentioned above, the values of these community descriptors were calculated on a sample basis, to be pooled every 15 $\mathrm{m}$ by averaging the sample values. Generalized additive models (GAM) were used to identify bathymetric trends in these community descriptors. Using GAM allowed us to avoid the arbitrariness of choosing a particular type of regression. Mean values of community descriptors were compared between areas and by assemblage identified in the cluster analysis using the $t$ test. Data were square-root or $\log (\mathrm{x}+1)$ transformed in order to meet the assumptions of normality and homogeneity of variances.

\section{Time series of species abundances}

The red shrimp fishery off the Balearic Islands is located on the middle slope below $500 \mathrm{~m}$ depth and has undergone an increase in the trawl fishing effort during the last few decades (Hidalgo et al., 2009, Palmer et al., 2009). In order to determine whether this increase has started to affect the elasmobranch species inhabiting these bottoms, linear regression was fitted to the relationship between the mean abundance, standardized to one square kilometre, of the most important elasmobranch species and year of the survey. For this analysis, the whole series of annual bottom trawl surveys in the Balearic Islands from 2001 to 2010 was used. Mean standardized abundance was calculated on a year basis taking into account hauls deeper than $500 \mathrm{~m}$ depth.

\section{RESULTS}

Taking into account both areas, a total of 29 elasmobranchs were caught (Table 2). Twelve species were common to both areas, 7 species appeared only in the Balearic Islands and 10 appeared only in Algeria. Eight of the captured species are considered as threatened in the Mediterranean according to the IUCN Red List of Threatened Species (Cavanagh and Gibson, 2007): Centrophorus granulosus, Galeorhinus galeus, Heptranchias perlo, Leucoraja circularis, Mustelus mustelus, Oxynotus centrina, Rostroraja alba
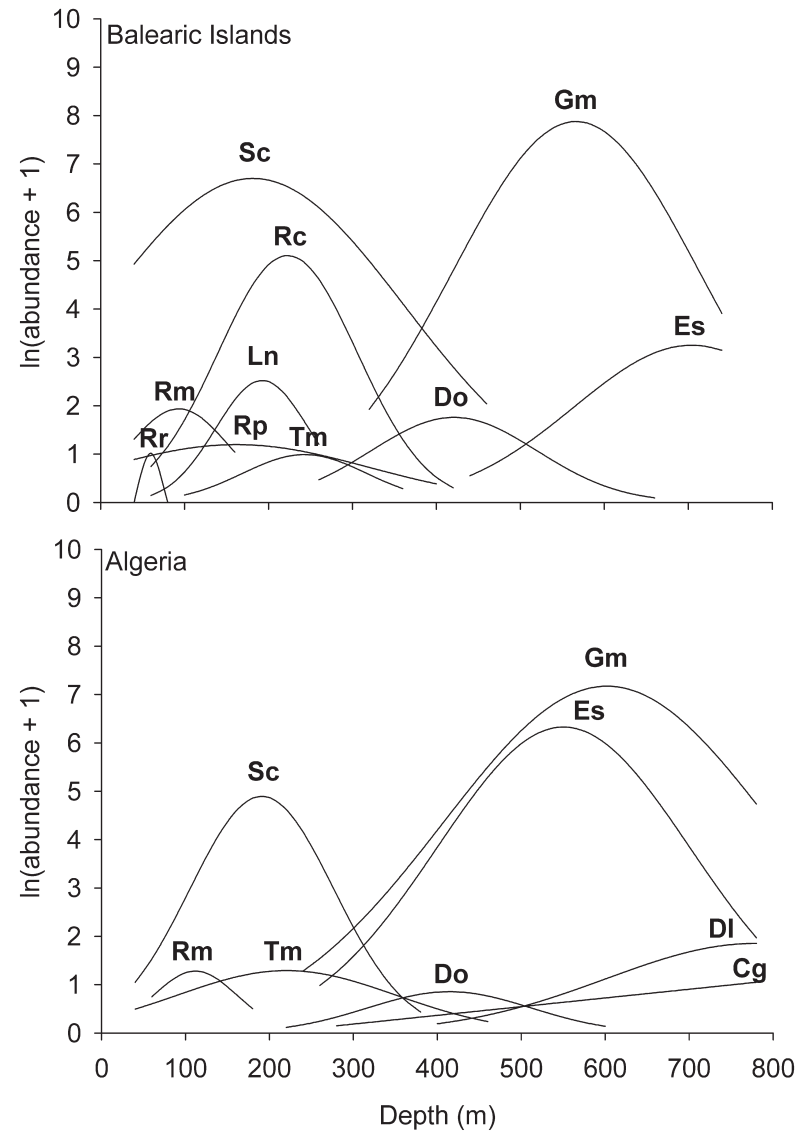

FIG. 2. - Bathymetric distribution models for the most frequent species in each area. Cg, C. granulosus; Dl, D. licha; Do, D. oxyrinchus; Es, E. spinax; Gm, G. melastomus; Ln, L. naevus; Rc, R. clavata; Rm, $R$. miraletus; Rp, $R$. polystigma; $\mathrm{Rr}, R$. radula; $\mathrm{Sc}, S$. canicula; Sb, S. blainvillei; Tm, T. marmorata

and Squalus acanthias. Except for M. mustelus, which appeared in both areas, and L. circularis and $R$. alba, which appeared only in the Balearic Islands, the rest of the threatened species appeared exclusively in Algeria. In the Balearic Islands, a total of 5368 individuals belonging to 9 families were captured, while the hauls carried out in Algeria yielded a total of 14956 individuals belonging to 11 families.

TABLE 3. - Results of the bathymetric distribution models. Type of the best fitting is indicated. Optimum depth (m) is shown in case of unimodal response; the $R^{2}$ is shown for linear responses $\left(\mathrm{Opt} . R^{-2}\right)$. Significance level $(P)$ of the regressions is also shown $(* * *=P<0.001)$.

\begin{tabular}{|c|c|c|c|c|c|c|}
\hline \multirow[t]{2}{*}{ Species } & \multicolumn{3}{|c|}{ Balearic Islands } & \multicolumn{3}{|c|}{ Algeria } \\
\hline & Response & Opt. $R^{-2}$ & $P$ & Response & Opt. $R^{-2}$ & $P$ \\
\hline C. granulosus & & & & linear & 0.65 & $* * *$ \\
\hline D. licha & & & & unimodal & 779 & $* * *$ \\
\hline D. oxyrinchus & unimodal & 421 & $* * *$ & unimodal & 414 & $* * *$ \\
\hline E. spinax & unimodal & 704 & $* * *$ & unimodal & 550 & $* * *$ \\
\hline G. melastomus & unimodal & 566 & $* * *$ & unimodal & 602 & $* * *$ \\
\hline L. naevus & unimodal & 192 & $* * *$ & & & \\
\hline R. clavata & unimodal & 223 & $* * *$ & & & \\
\hline R. miraletus & unimodal & 93 & $* * *$ & unimodal & 112 & $* * *$ \\
\hline R. polystigma & unimodal & 162 & $* * *$ & & & \\
\hline R. radula & unimodal & 63 & $* * *$ & & & \\
\hline S. canicula & unimodal & 182 & $* * *$ & unimodal & 191 & $* * *$ \\
\hline T. marmorata & unimodal & 243 & $* * *$ & unimodal & 221 & $* * *$ \\
\hline
\end{tabular}



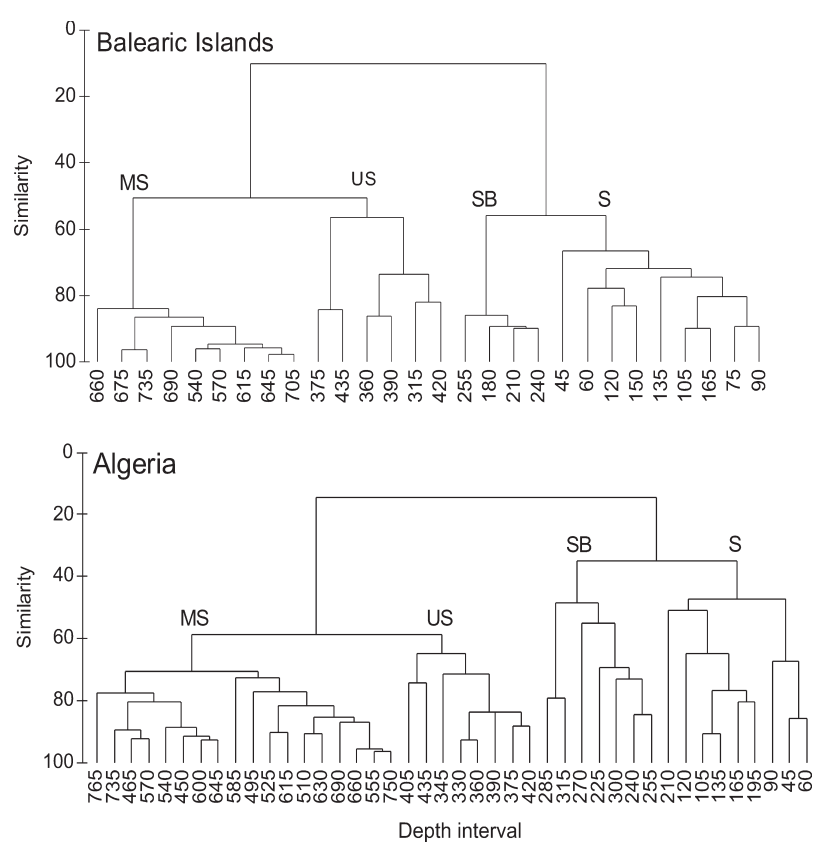

FIG. 3. - Cluster analyses showing the assemblages identified in each area. S, shelf; SB, shelf-break; US, upper slope; MS, middle slope. Samples are labelled with the shallowest depth limit $(\mathrm{m})$ of the 15-metre depth intervals considered for these analyses.

\section{Bathymetric distribution of species}

Except for Centrophorus granulosus in Algeria, the bathymetric distributions of species were best fitted to uni-modal response curves than to linear regressions (Table 3 and Fig. 2). The models for species common to both areas showed a similar bathymetric distribution. Etmopterus spinax was the species that displayed most differences in its optimum value, which in Algeria was located $154 \mathrm{~m}$ shallower than in the Balearic Islands.
TABLE 4. - SIMPER results for each elasmobranch assemblage identified in each area from cluster analysis. $\overline{\mathrm{Y}}$ : mean yields $\left(\mathrm{kg} \mathrm{km}^{-2}\right) ; \overline{\mathrm{S}}_{\mathrm{i}}$, average similarity; SD, standard deviation; $\% \mathrm{~S}_{\mathrm{i}}$, percentage contribution to the similarity.

\begin{tabular}{|c|c|c|c|c|c|}
\hline Balearic Islands & $\overline{\mathrm{Y}}$ & $\overline{\mathrm{S}}_{\mathrm{i}}$ & $\overline{\mathrm{S}}_{\mathrm{i}} / \mathrm{SD}$ & $\% \overline{\mathrm{S}}_{\mathrm{i}}$ & $\sum \overline{\mathrm{S}}_{\mathrm{i}} \%$ \\
\hline \multicolumn{6}{|l|}{ Shelf $\bar{S}_{\mathrm{i}}=73.6$} \\
\hline S. canicula & 753.1 & 44.23 & 8.21 & 60.11 & 60.11 \\
\hline R. clavata & 59.7 & 10.09 & 2.2 & 13.72 & 73.83 \\
\hline$R$. miraletus & 39.3 & 8.67 & 3.1 & 11.78 & 85.61 \\
\hline R. polystigma & 18.3 & 5.65 & 3.56 & 7.68 & 93.29 \\
\hline \multicolumn{6}{|l|}{ Shelf break $\quad S_{i}=87.6$} \\
\hline S. canicula & 3414.8 & 67.93 & 18.51 & 77.5 & 77.5 \\
\hline R. clavata & 203.2 & 14.52 & 4.52 & 16.57 & 94.07 \\
\hline \multicolumn{6}{|l|}{ Upper slope $\overline{\mathrm{S}}_{\mathrm{i}}=66.5$} \\
\hline G. melastomus & 667.8 & 41.65 & 3.5 & 62.59 & 62.59 \\
\hline S. canicula & 120.6 & 21.24 & 3.75 & 31.93 & 94.52 \\
\hline \multicolumn{6}{|l|}{ Middle slope $\overline{\mathrm{S}}_{\mathrm{i}}=88.9$} \\
\hline G. melastomus & 340.3 & 67.89 & 11.5 & 76.39 & 76.39 \\
\hline E. spinax & 34.0 & 20.99 & 7.65 & 23.61 & 100 \\
\hline \multicolumn{6}{|l|}{ Algeria } \\
\hline \multirow{2}{*}{\multicolumn{6}{|c|}{ Shelf $\overline{\mathrm{S}}_{\mathrm{i}}=57.4$}} \\
\hline & & & & & \\
\hline S. canicula & 322.2 & 41.8 & 2.5 & 72.8 & 72.8 \\
\hline T. marmorata & 7.4 & 6.1 & 1.1 & 10.6 & 83.5 \\
\hline R. miraletus & 8.4 & 5.8 & 0.8 & 10.0 & 93.5 \\
\hline \multicolumn{6}{|l|}{ Shelf break $\bar{S}_{\mathrm{i}}=57.6$} \\
\hline G. melastomus & 87.8 & 32.0 & 2.9 & 55.5 & 55.5 \\
\hline S. canicula & 93.6 & 20.2 & 1.6 & 35.0 & 90.5 \\
\hline \multicolumn{6}{|l|}{ Upper slope $\quad \overline{\mathrm{S}}_{\mathrm{i}}=72.9$} \\
\hline E. spinax & 876.1 & 41.7 & 4.2 & 57.2 & 57.2 \\
\hline G. melastomus & 259.1 & 25.5 & 4.6 & 35.0 & 92.2 \\
\hline \multicolumn{6}{|l|}{ Middle slope $\overline{\mathrm{S}}_{\mathrm{i}}=74.6$} \\
\hline G. melastomus & 1314.6 & 47.9 & 5.9 & 64.2 & 64.2 \\
\hline E. spinax & 260.9 & 20.9 & 3.9 & 28.1 & 92.3 \\
\hline
\end{tabular}

\section{Assemblages and community descriptors}

The cluster analysis identified four bathymetric assemblages in the Balearic Islands and Algeria, with similar depth ranges (Fig. 3): (i) continental shelf at 45180 and 45-225 m, respectively; (ii) shelf-break at 180-

TABLE 5. - Average values and standard errors of the community descriptors by assemblage and area. Abundance and biomass are given in individuals and $\mathrm{kg} \mathrm{km}^{-2}$, respectively. MFW, mean fish weight (g); S, Species richness (number of species); H', Shannon's diversity index. The results of the $t$ test comparing the mean values are also shown. df, degrees of freedom. Significance level: $*, P<0.05 ; * *, P<0.01 ; * * *$, $P<0.001$; ns, non-significant.

\begin{tabular}{|c|c|c|c|c|c|c|}
\hline Assemblage & Index & Balearic Islands & Algeria & $t$ value & df & $P$ \\
\hline \multirow[t]{5}{*}{ Shelf } & Abundance & $925.21 \pm 137.07$ & $165.62 \pm 41.66$ & 6.2 & 16 & $* * *$ \\
\hline & Biomass & $191.06 \pm 29.31$ & $50.26 \pm 8.58$ & 5.6 & 16 & $* * *$ \\
\hline & MFW & $234.17 \pm 37.87$ & $398.23 \pm 35.77$ & -3.2 & 16 & $* *$ \\
\hline & $\mathrm{S}$ & $2.91 \pm 0.18$ & $1.63 \pm 0.28$ & 4.1 & 16 & $* * *$ \\
\hline & $\mathrm{H}^{\prime}$ & $0.55 \pm 0.06$ & $0.3 \pm 0.1$ & 2.4 & 16 & $*$ \\
\hline \multirow[t]{5}{*}{ Shelf break } & Abundance & $2936.24 \pm 883.26$ & $592.12 \pm 246.67$ & 3.1 & 9 & $* *$ \\
\hline & Biomass & $209.96 \pm 109.44$ & $61.68 \pm 31.45$ & 2.0 & 9 & $*$ \\
\hline & MFW & $69.42 \pm 22.02$ & $115.16 \pm 17.3$ & -1.9 & 9 & n.s. \\
\hline & $\mathrm{S}$ & $3.5 \pm 0.41$ & $1.88 \pm 0.21$ & 4.2 & 9 & $* *$ \\
\hline & $\mathrm{H}^{\prime}$ & $0.41 \pm 0.15$ & $0.33 \pm 0.12$ & 0.7 & 9 & n.s. \\
\hline \multirow[t]{5}{*}{ Upper slope } & Abundance & $1175.15 \pm 670.1$ & $805.13 \pm 270.76$ & 0.4 & 12 & n.s. \\
\hline & Biomass & $41.23 \pm 18.67$ & $41.06 \pm 11.64$ & -0.3 & 12 & n.s. \\
\hline & MFW & $64.97 \pm 18.75$ & $53.16 \pm 16.88$ & 0.4 & 12 & n.s. \\
\hline & $\mathrm{S}$ & $2.46 \pm 0.44$ & $2.6 \pm 0.15$ & -0.6 & 12 & n.s. \\
\hline & $\mathrm{H}^{\prime}$ & $0.35 \pm 0.1$ & $0.46 \pm 0.05$ & -1.3 & 12 & n.s. \\
\hline \multirow[t]{5}{*}{ Middle slope } & Abundance & $374.25 \pm 39.07$ & $1468.24 \pm 231.23$ & -4.8 & 28 & $* * *$ \\
\hline & Biomass & $76.86 \pm 13.21$ & $288.93 \pm 57.85$ & -3.6 & 28 & $* *$ \\
\hline & MFW & $207.71 \pm 29.51$ & $214.57 \pm 31.62$ & 0.3 & 28 & n.s. \\
\hline & $\mathrm{S}$ & $1.89 \pm 0.14$ & $3.08 \pm 0.21$ & -3.9 & 28 & $* * *$ \\
\hline & $\mathrm{H}^{\prime}$ & $0.3 \pm 0.05$ & $0.54 \pm 0.04$ & -3.3 & 28 & $* *$ \\
\hline
\end{tabular}


TABLE 6. - Summary of GAM's modelling the relationship of the community descriptors with depth, by area. Abbreviations, units and $P$-values are given as in Table 5. $R^{2}, R$ squared; DE, percentage of deviance explained.

\begin{tabular}{lcccccc}
\hline \multirow{2}{*}{ Indexes } & \multicolumn{3}{c}{ Balearic Islands } & \multicolumn{3}{c}{ Algeria } \\
& $R^{2}$ & $\mathrm{DE}$ & $P$ & $R^{2}$ & $\mathrm{DE}$ & $P$ \\
\hline Abundance & 0.244 & 32.0 & $*$ & 0.285 & 30.1 & $* * *$ \\
Biomass & 0.27 & 32.1 & $*$ & 0.739 & 75.6 & $* * *$ \\
MFW & 0.535 & 57.8 & $* * *$ & 0.779 & 79.3 & $* * *$ \\
S & 0.501 & 55.4 & $* * *$ & 0.331 & 35.4 & $* * *$ \\
H' & 0.154 & 18.5 & $*$ & 0.173 & 20.4 & $*$ \\
\hline
\end{tabular}

270 and 225-330 m, respectively; (iii) upper slope at 315-450 and 330-450 m, respectively; and (iv) middle slope at 545-750 and 450-765 m, respectively. However, SIMPER analysis showed that the species composition of these assemblages differed greatly between areas (Table 4). On the continental shelf Scyliorhinus canicula was the most important species in terms of within-group similarity contribution, both in the Balearic Islands and Algeria (60\% and $73 \%$, respectively). The Balearic Islands also showed a high similarity contribution of Rajidae species (Raja clavata, Raja miraletus and Raja polystigma), whereas in Algeria the rest of the important contributors were the Torpedinidae species Torpedo marmorata and $R$. miraletus. The most important species on the shelf break off the Balearic Islands were $S$. canicula and $R$. clavata, whereas in Algeria this assemblage was mainly dominated by Galeus melastomus and S. canicula. The species composition on the upper slope was also different, with $G$. melastomus and S. canicula as main contributors to this assemblage in the Balearic Islands, and E. spinax and G. melastomus as main contributors to this assemblage in Algeria. The middle slope was similar in the two areas, with $G$. melastomus and E. spinax being the main contributors in both areas but with higher mean abundances for both species in Algeria. ANOSIM detected significant differences between areas for all the bathymetric assemblages (Shelf: $R=0.724, P<0.01$; Shelf-break: $R=0.974, P<0.01$; Upper slope: $R=0.989$, $P<0.01$; Middle slope: $R=0.69, P<0.01$ ).

The $t$ test comparing, for each assemblage, the mean values of abundance, biomass and species richness between areas, showed that for the continental shelf and shelf break all these indexes were higher in the Balearic Islands, whereas no differences were detected on the upper slope and higher values were detected on the middle slope of Algeria. The MFW only displayed significant differences when shelf assemblages were compared, mean values being higher in Algeria. Mean values of H' were higher on the continental shelf of the Balearic Islands, whereas no differences were detected on the shelf break and upper slope, and higher mean values were detected on the middle slope of Algeria (Table 5).

The GAM analyses applied to the community descriptors explained a significant percentage of deviance in all cases (Table 6). GAM models showed dif-
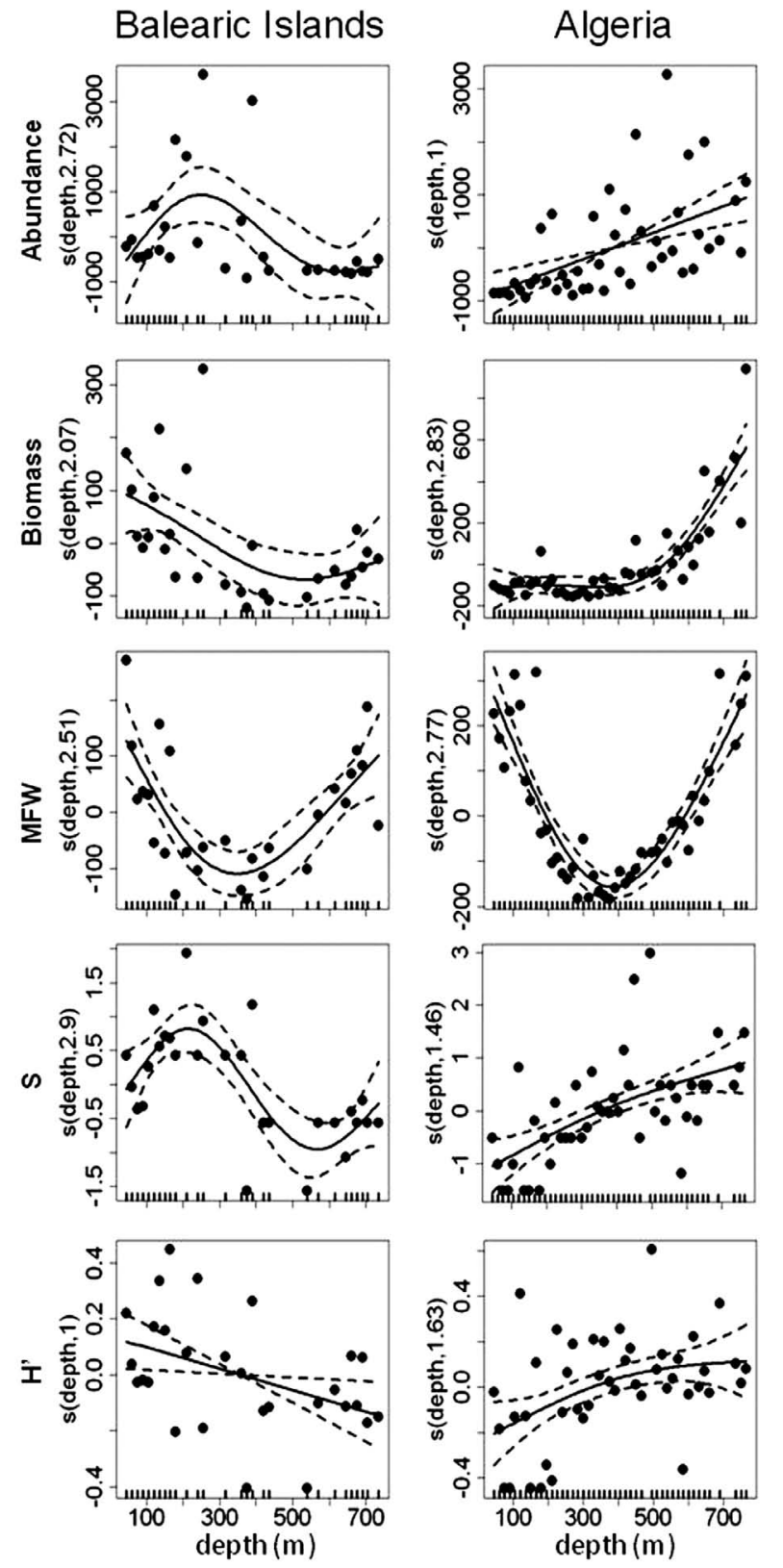

FIG. 4. - GAM results. Solid lines represent the expected trend of each community descriptor in relation to depth. Dashed lines represent the $95 \%$ confidence envelopes, and points are the residual values of each sample. Abbreviations and units of descriptors are as in Table 5.

ferent between-area bathymetric trends for all the descriptors, with the exception of MFW (Fig. 4), which showed a u-shaped pattern, with its minimum around $400 \mathrm{~m}$ depth in both areas. In the Balearic Islands, the abundance and the species richness displayed a general pattern of increasing values down to around $300 \mathrm{~m}$ depth, with a subsequent pronounced decrease down to around $600 \mathrm{~m}$, a depth at which these indices seemed to start to increase again, but with larger 95\% confidence envelopes. The biomass showed a decreasing trend from the shelf down to around 

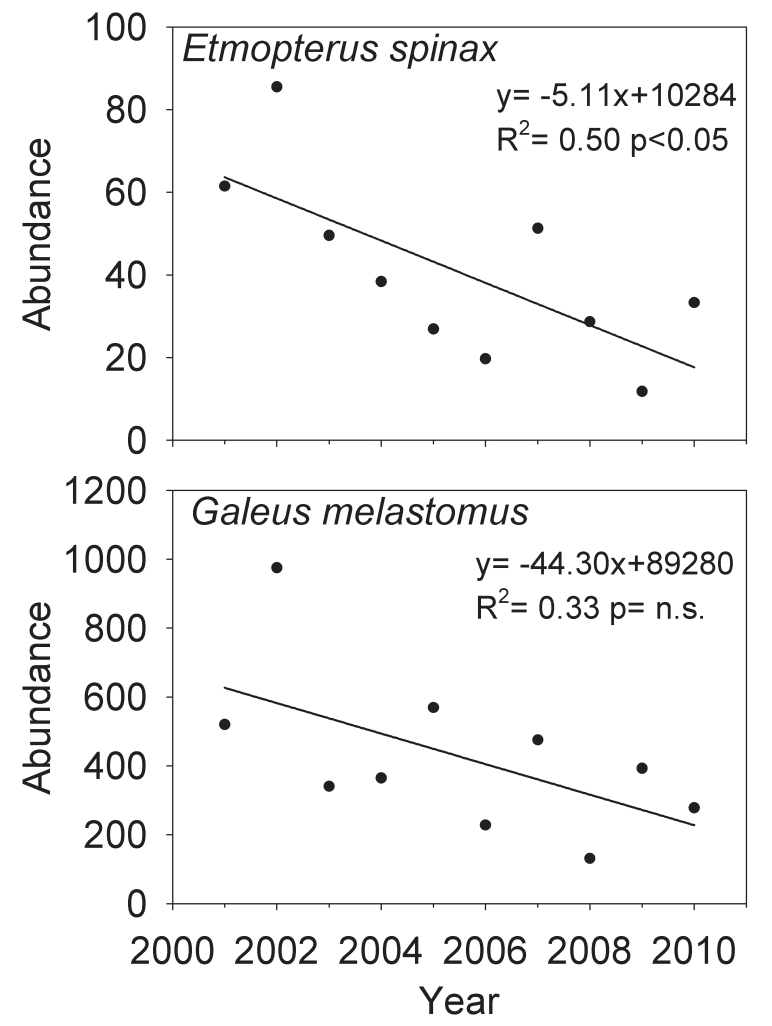

FIG. 5. - Average abundance (ind. $\mathrm{km}^{-2}$ ) of E. spinax and G. melastomus in the red shrimp fishery off the Balearic Islands (samples deeper than $500 \mathrm{~m}$ ) in each annual survey. Parameters and level of significance of the regression are also shown.

$600 \mathrm{~m}$, where it also seemed to start to increase again, whereas the diversity showed a decreasing trend throughout the whole bathymetric range sampled. In Algeria, these descriptors showed an increasing trend along the whole bathymetric range, with the exception of biomass, which started to increase at around $400 \mathrm{~m}$ depth.

\section{Time series of species abundances}

Linear regressions were applied to the relationship between mean standardized abundance and year for the most important elasmobranch species in the red shrimp fishery (middle slope) off the Balearic Islands. According to the SIMPER analysis these species were E. spinax and G. melastomus (Table 4). Both species showed a decreasing trend, although it was only significant in the case of E. spinax (Fig. 5).

\section{DISCUSSION}

According to the published data on the number of demersal elasmobranch species in the western Mediterranean (see Massutí and Moranta, 2003), the Balearic Islands and Algeria should be considered among the areas with highest diversity in this basin. The total number of species was higher in Algeria than in the Balearic Islands, 22 and 19, respectively. Overall, there was a higher number of shark species in Algeria than in the Balearic Islands (13 and 6, respectively), and a lower number of batoids (9 and 13, respectively). In the case of batoids, the differences are clearly due to the higher number of Rajidae species in the Balearic Islands than in Algeria (10 and 4, respectively), this family being the most numerous one in terms of number of species in both areas. These estimations must be restricted to the circa-littoral soft bottoms suitable for bottom trawl fishery, which in Algeria only represent one third of the continental shelf surface (GFCM, 1980). In fact, 14 of the 16 Rajidae species reported in the Mediterranean (Serena et al., 2010) have also been found in Algeria, but only after nine years monitoring the landings from all commercial fisheries in the area (Hemida et al., 2007). Moreover, the list of Rajidae species includes species that, according to the authors, had become rare (Leucoraja circularis, Leucoraja melitensis and Leucoraja naevus) or even disappeared (Rostroraja alba) by 2004.

Eight captured species are considered as threatened elasmobranchs in the Mediterranean. Most of them were mainly distributed on the slope: the sharks Centrophorus granulosus, Galeorhinus galeus, Heptranchias perlo, Oxynotus centrina and Squalus acanthias (all of them only appearing in Algeria), and the skate $L$. circularis (only appearing in the Balearic Islands), and also Mustelus mustelus, a species appearing on the shelf of both areas but more frequently in Algeria, and $R$. alba, appearing only on the shelf of the Balearic Islands. Although human disturbance, habitat loss and degradation, and recreational fisheries pose a threat to a number of elasmobranchs in the Mediterranean, commercial fisheries have been considered as the biggest threat to these species in the area (Cavanagh and Gibson, 2007). Thus, the higher presence and abundance of threatened deep-water sharks in Algeria may be due to the lower development of the deep water trawl fishery in this area than in the Balearic Islands (Mouffok et al., 2008). Moreover, Etmopterus spinax, a shark considered as extremely vulnerable to fishing mortality due to its late maturation, long reproductive cycle and low fecundity (Coelho and Erzini, 2005, 2008), was present at shallower depths and showed higher abundances in Algeria than in the Balearic Islands.

Our analyses detected four elasmobranchs assemblages related to depth (shelf, shelf-break, upper slope and middle slope) in both areas, with almost identical depth ranges. These bathymetric strata are coincident with the assemblages of demersal macro-fauna in the western (Massutí and Reñones, 2005), central (Biagi et al., 2002; Colloca et al., 2003) and eastern (Kallianiotis et al., 2000) Mediterranean.

Though the depth range of the elasmobranch assemblages detected in the Balearic Islands and Algeria were similar, very clear differences were observed in their species composition. Whereas in the Balearic Islands the importance of Rajidae in terms of contribution to the assemblages was high down to the shelf 
break, Raja miraletus was the only Rajidae species that appeared to be relatively important in Algeria, and it was restricted to the shelf assemblage. These differences can be explained by the different type of bottoms in the two areas (see below).

Traditional descriptors applied to compare elasmobranch assemblages between areas showed higher values on the shelf and shelf-break off the Balearic Islands, except for mean fish weight. The differences disappeared on the upper slope and appeared again on the middle slope, but because of higher values in Algeria. In agreement with these results, the GAM analyses showed a general depth-decreasing trend in the Balearic Islands, whereas a depth-increasing trend appeared in Algeria, with the exception of mean fish weight, the only descriptor showing the same trend in both areas. This index appeared to be highly sensitive to the distribution of recruits and juveniles of the most abundant species and displayed a u-shaped plot related to depth, with a minimum located on the upper slope, where juveniles of Scyliorhinus canicula, Galeus melastomus and E. spinax have their maximum abundances throughout the Mediterranean (Tursi et al., 1993; D’Onghia et al., 1995; Carbonell et al., 2003; Massutí and Moranta, 2003).

The distinct environmental scenarios and fishing histories could be the basis for the differences detected in the total abundance and biomass, species richness and diversity between the two areas. On the one hand, the higher values detected on the shelf and shelfbreak off the Balearic Islands than off Algeria could be explained by the heterogeneity of bottoms, their sediment type and the widespread presence of sensitive and essential fish habitats in the former area (e.g. soft red algae, maërl and crinoids beds; Ordines and Massutí, 2009). The heterogeneity of the seabed has been considered as an important factor that enhances the diversity of demersal fish species (Rogers et al., 1999). Moreover, a recent study by Damalas et al. (2009) has shown that sediment type has a considerable effect on the distribution and habitat selection of benthic Rajidae in the Mediterranean, stating that the four Rajidae species studied (Raja clavata, L. naevus, R. miraletus and Raja montagui) have "an unmistakable preference for sandy bottoms". This preference had already been documented, being partially attributed to the distribution of their preferred preys (Jardas, 1973; Skjæraasen and Bergstad, 2000). The biogenic sand and gravel bottoms of the Balearic shelf (Fornós et al., 1988) can benefit these species, while their presence is much lower off Algeria, where terrigenous muddy bottoms are widespread even on the coastal continental shelf, and specifically on the trawling grounds (Le Danois et al., 1924; Maurin, 1968; Bakalem et al., 1981), where our sampling was carried out. Rajidae almost disappear on the slope, where muddy bottoms are predominant in both areas. The presence of widespread muddy bottoms on the Algerian continental shelf could also explain the importance of the Torpedinidae family in that area, where Torpedo marmorata ranked second in importance on the shelf. In fact $T$. marmorata has been reported to have its maximum abundances on muddy bottoms with low sand contents and a decreasing trend as sand proportion and carbonates in the sediments increase (Damalas et al., 2010). Moreover, whereas $T$. marmorata was the only Torpedinidae species detected in the Balearic Islands and was restricted to depths below $100 \mathrm{~m}$, two other species of this family appeared in Algeria (Torpedo nobiliana and Torpedo torpedo), with T. marmorata and $T$. torpedo appearing at the shallowest depths sampled.

The reduction of the bottom trawl fishing effort on the shelf bottoms of the Balearic Islands during the last few decades owing to the displacement of this fishery towards greater depths (Moranta et al., 2008) and the reinforcement (or extension) of some areas currently closed to trawling in the Balearic Islands (e.g. areas with submarine cables, marine protected areas and fishermen's agreement to avoid trawling in some areas of the shelf during summer) should have positively influenced the continental shelf elasmobranch populations, thus raising the values of the community descriptors. Similarly, the higher values detected for these descriptors on the middle slope of Algeria could be explained by favourable environmental conditions and/or the low fishing pressure historically exerted on these bottoms. The unusually high primary production of the nearby Alboran sea (Cartes et al., 2002), along with the influence of Atlantic currents entering the Mediterranean through the Strait of Gibraltar, the stable presence of the Almeria-Oran front, and the existence of numerous submarine canyons, provide an environmental scenario that is favourable to the enrichment of the deep waters on the Algerian slope. Furthermore, according to Nouar (2001), the deep sea red shrimp fishery (below $400 \mathrm{~m}$ depth) remained unexploited at the end of the last century owing to the lack of deep-water trawling equipment, though it started to increase steadily at the beginning of the current century (Mouffok et al., 2008). However, the fishing pressure seems to have a greater effect than environmental conditions when species-specific aspects are taken into account. In both areas the middle slope bottoms are characterized by the dominance of $G$. melastomus and $E$. spinax. This last species is considered as extremely vulnerable to fishing impacts even within the general context of high elasmobranch vulnerability (Coelho and Erzini, 2008), and was much more abundant in the slope assemblages off Algeria than in those off the Balearic Islands. Although the bottom trawl survey series in the Balearic Islands is relatively short (10 years, including late springsummer surveys), E. spinax shows a clear decline in abundance in the red shrimp fishery of that area, indicating that the displacement of the fishing effort to these bottoms during the last decades (Hidalgo et al., 2009) could have started to show its effects on the most vulnerable species. Caution should be taken with these results, because $G$. melastomus shows no significant 
trend for the same period. This species should have a higher resilience than E. spinax because of its shorter reproductive cycle and higher fecundity (Capapé et al., 2008). Furthermore, there is no comparable time series of the abundance of $E$. spinax in Algerian waters, so its trend during the same period is unknown.

Rogers et al. (1999) pointed out the difficulties that arise when one is trying to disentangle environmental from fishing effects, dealing with community indexes. These authors suggested that one solution to this problem could come from the use of "specific aspects of the assemblage, with emphasis on selected vulnerable species rather than the community as a whole". Elasmobranchs are especially vulnerable to fishing impacts (Stevens et al., 2000). The present paper has dealt with two nearby areas with different fishing histories, especially for the slope bottoms. However, the coincidence of higher values of the community descriptors, with lower fishing exploitation levels and apparently favourable environmental conditions, made it difficult to discern the effects attributable to each one. Nevertheless, the use of the traditional community descriptors applied to elasmobranch populations, as in the present study, could be a suitable tool for monitoring the impact of fishing exploitation in the ecosystems of the Mediterranean, as the vulnerability of these species (some of them considered as threatened) could help to evidence its effects long before they are evident in more resilient target species.

\section{ACKNOWLEDGEMENTS}

This paper is a result of the MEDER, DEMO, EVADEM, EVADEMED and BADEMECO projects, financed by the IEO and, as of 2007, by the EU. The authors wish to thank all the participants in the sampling.

\section{REFERENCES}

Acosta, A., M. Canals, J. López-Martínez, A. Muñoz, P. Herranz, R. Urgeles, C. Palomo and J.L. Casamor. - 2002. The Balearic Promontory geomorphology (western Mediterranean): morphostructure and active processes. Geomorphology, 49: 177-204

Bakalem, A., C. Hily and J.C. Romano. - 1981. Contribution à l'étude des peuplements benthiques de la Baie d'Alger. Cartographie et definition des peuplements. Pelagos, 6(2): 8-111.

Ballesteros, E. - 1994. The deep-water Peyssonnelia beds from the Balearic Islands (western Mediterranean). P.S.Z.N.I. Mar. Ecol., 15: 233-253.

Benzhora, M. and C. Millot. - 1995. Characteristics and circulation of the surface and intermediate water masses off Algeria. DeepSea Res. Part I-Oceanogr. Res. Pap., 42: 1803-1830.

Bertrand J.A., Gil de Sola L., Papaconstantinou C., Relini G., Souplet A. 2000. Contribution on the distribution of elasmobranchs in the Mediterranean (from the MEDITS surveys). Biol. Mar. Mediterr., 7: 1-15.

Bertrand, J.A., L. Gil de Sola, C. Papaconstantinou, G. Relini and A. Souplet. - 2002. The general specifications of the MEDITS surveys. Sci. Mar., 66(2): 9-17.

Biagi, F., P. Sartor, G.D. Ardizzone, P. Belcari, A. Belluscio and F. Serena. - 2002. Análisis of demersal assemblages off Tuscany and Latium coasts (north-western Mediterranean). Sci. Mar., 66: 233-242

Canals, M. and E. Ballesteros. - 1997. Production of carbonate particles by phytobenthic communities on the Mallorca-Menorca shelf, northwestern Mediterranean Sea. Deep-Sea Res. Part IITop. Stud. Oceanogr., 44: 611-629.

Capapé, C., O. Guélorget, Y. Vergne and C. Reynaud. - 2008. Reproductive biology of the blackmouth catshark, Galeus melastomus (Chondrichthyes: Scyliorhinidae) off the Languedocian coast (Southern France, northern Mediterranean). J. Mar. Biol. Assoc. U.K., 88: 415-421.

Capapé, C., J.A. Tomasini and J.P. Quignard. - 2000. Les Elasmobranches Pleurotrêmes de la côte du Languedoc (France méridionale, Méditerranée septentrionale). Observations biologiques et démographiques. Vie Milieu, 50: 123-133.

Carbonell, A., F. Alemany, P. Merella, A. Quetglas and E. Román. - 2003. The by-catch of sharks in the western Mediterranean (Balearic Islands) trawl fishery. Fish. Res., 61: 7-18.

Carbonell, A. and M. Azevedo. - 2003. Application of non-equilibrium production models to the red shrimp (Aristeus antennatus Risso, 1816) fishery in the northwestern Mediterranean. Fish. Res., 65: 323-334.

Cartes, J.E., P. Abelló, D. Lloris, A. Carbonell, P. Torres, F. Maynou and L. Gil de Sola. - 2002. Feeding guilds of western Mediterranean demersal fish and crustaceans: an analysis based on a spring survey. Sci. Mar., 66: 209-220.

Cavanagh, R.D. and C. Gibson. - 2007. Overview of the Conservation Status of Cartilaginous Fishes (Chondrichthyans) in the Mediterranean Sea. IUCN, Gland, Switzerland and Málaga,

Coelho, R. and K. Erzini. - 2005. Length at first maturity of two species of lantern sharks (Etmopterus spinax and Etmopterus pusillus) of southern Portugal. J. Mar. Biol. Assoc. U.K., 85: 1163-1165.

Coelho, R. and K. Erzini. - 2008. Life history of a wide-ranging deepwater lantern shark in the north-east Atlantic, Etmopterus spinax (Chondrichthyes: Etmopteridae), with implications for conservation. J. Fish Biol., 73: 1419-1443.

Colloca, F., M. Cardinale, A. Belluscio and G.D. Ardizzone. -2003. Structure and diversity of demersal assemblages in the central Mediterranean Sea. Estuar. Coast. Shelf Sci., 56: 469-480.

Damalas, D., S. Katsanevakis, C.D. Maravelias, A.P. Karageorgis, C. Anagnostou, E. Tsitsika and C. Papaconstantinou. - 2009. Habitat preferences and spatio-temporal distribution of four benthic skates in the eastern Mediterranean Sea. Proceeding of the $9^{\text {th }}$ Symposium on Oceanography and Fisheries, 2: 771-776.

Damalas, D., C.D. Maravelias, S. Katsanevakis, A.P. Karageorgis and C. Papaconstantinou. - 2010. Seasonal abundance of noncommercial demersal fish in the eastern Mediterranean Sea in relation to hydrographic and sediment characteristics. Estuar. Coast. Shelf. Sci., 89: 107-118.

D’Onghia, G., A. Matarrese, A. Tursi and L. Sion. - 1995. Observations on the depth distribution pattern of the small-spotted catshark in the North Aegean Sea. J. Fish Biol., 47: 421-426.

Estrada, M. - 1996. Primary production in the northwestern Mediterranean. Sci. Mar., 60(2): 55-64.

Fornós, J.J., E. Ballesteros, C. Massutí and A. Rodríguez-Perea. 1988. Red algae sediments in the Balearic Shelf. Rapp. Comm. int. Mer Médit., 31: 2.

GFCM. - 1980. La pêcherie algérienne. FAO Rap. Pêches, 227: 51-60.

Hemida, F., W. Sergoua and R. Seridji. - 2007. Nouvelle liste commentée des raies du bassin algérien. Rapp. Comm. int. Mer Médit., 38: 497.

Hidalgo, M., E. Massutí, B. Guijarro, J. Moranta, L. Ciannelli, J. Lloret, P. Oliver and N.C. Stenseth. - 2009. Population effects and changes in life history traits in relation to phase transitions induced by long-term fishery harvesting: European hake (Merluccius merluccius) off the Balearic Islands. Can. J. Fish. Aquat. Sci., 66: 1355-1370.

Jardas, I. - 1973. A contribution to our knowledge of the biology and ecology of thornback ray (Raja clavata L.) and brown ray (Raja miraletus L.) in the Adriatic. Acta Adriat., 15(3): 1-42.

Kallianiotis, A., K. Sophronidis, P. Virodis and A. Tselepides. 2000. Demersal fish and megafaunal assemblages on the Cretan continental shelf and slope (NE Mediterranean): seasonal variation in species density, biomass and diversity. Prog. Oceanogr., 46: 429-455.

Le Danois, E., M.M.G. Belloc, R. Rallier du Baty and G. Ranson. - 1925. Recherches sur les fonds chalutables des côtes de Tunisie et d'Algérie (Croisière du Chalutier "Tanche" en 1924). Blondel la Rougery, Paris. 
Massutí, E. and J. Moranta. - 2003. Demersal assemblages and depth distribution of elasmobranches from the continental shelf and slope off the Balearic Islands (western Mediterranean). ICES J. Mar. Sci., 60: 753-766.

Massutí, E. and O. Reñones. - 2005. Demersal resource assemblages in the trawl fishing grounds off the Balearic Islands (western Mediterranean). Sci. Mar., 69: 167-181.

Maurin, C. - 1968. Ecologie ichthyologique des fonds chalutables atlantiques (de la Baie Ibero-Marocaine a la Mauritanie) et de la Mediterranee occidentale. Revue des travaux de l'Institut des pêches maritimes, 32(1): 1-144.

Millot, C. - 1999. Circulation in the western Mediterranean Sea. J. Mar. Syst., 20: 423-442.

Monserrat, S., J.L. López-Jurado and M. Marcos. - 2008. A mesoscale index to describe the regional circulation around the Balearic Islands. J. Mar. Syst., 71: 413-420.

Moranta, J., A. Quetglas, E. Massutí, B. Guijarro, M. Hidalgo and P. Díaz. - 2008. Spatio-temporal variations in deep-sea demersal communities off the Balearic Islands (western Mediterranean). J. Mar. Syst., 71: 346-366.

Mouffok, S., E. Massutí, Z. Boutiba, B. Guijarro, F. Ordines and K. Fliti. - 2008. Ecology and fishery of the deep-water shrimp, Aristeus antennatus (Risso, 1816) off Algeria (south-western Mediterranean). Crustaceana, 81(10): 1177-1199.

Nouar, A. - 2001. Bio-écologie de Aristeus antennatus (Risso, 1816) et de Parapenaeus longirostris (Lucas, 1846) des côtes Algériennes. Rapp. Comm. int. Mer Médit., 36: 304.

Ordines, F. and E. Massutí. - 2009. Relationships between macroepibenthic communities and fish on the shelf grounds of the western Mediterranean. Aquat. Conserv.-Mar. Freshw. Ecosyst., 19: 370-383.

Palmer, M., A. Quetglas, B. Guijarro, J. Moranta, F. Ordines and E. Massutí. - 2009. Performance of artificial neural networks and discriminant analysis in predicting fishing tactics from multiespecific fisheries. Can. J. Fish. Aquat. Sci., 66: 224-237.

Pinot, J.M., J.L. Lopez-Jurado and Riera M. - 2002. The CANALES experiment (1996-1998). Interannual, seasonal, and mesoscale variability of the circulation in the Balearic Channels. Prog. Oceanogr., 55: 335-370.

Relini, G., F. Biagi, F. Serena, A. Belluscio, M.T. Spedicato, P.
Rinelli, M.C. Follesa, C. Piccinetti, N. Ungaro, L. Sion and D. Levi. - 2000. I Selaci pescati con lo strascico nei mari italiani. Biol. Mar. Mediterr., 7: 347-384.

Rogers, S.I., D. Maxwell, A.D. Rijnsdorp, U. Damm and W. Vanhee. -1999 . Fishing effects in northeast Atlantic shelf seas: patterns in fishing effort, diversity and community structure. IV. Can comparisons of species diversity be used to assess human impacts on demersal fish fauna. Fish. Res., 40: 135-152.

Serena, F., C. Mancusi and M. Barone. - 2010. Field identification guide to the skates (Rajidae) of the Mediterranean Sea. Guidelines for data collection and analysis. Biol. Mar. Mediterr., 17 (Suppl. 2): 204 pp.

Skjæraasen, J.E. and O.A. Bergstad. - 2000. Distribution and feeding ecology of Raja radiata in the northeastern North Sea and Skagerrak (Norwegian Deep). ICES J. Mar. Sci., 57: 1249-1260.

Stevens, J.D., R. Bonfil, N.K. Dulvy and P.A. Walker. - 2000. The effects of fishing on sharks, rays, and chimaeras (chondrichthyans), and the implications for marine ecosystems. ICES J. Mar. Sci., 57: 476-494.

Ter Braak, C.J. - 1986. Canonical correspondence analysis: a new eigenvector technique for multivariate direct gradient analysis. Ecology, 67(5): 1167-1179.

Ter Braak, C.J.F. and P. Smilauer. - 2002. CANOCO reference manual and user's guide to Canoco for windows: software for canonical community ordination (version 4.5). Microcomputer Power: Ithaca, New York.

Tursi, A., G. D’Onghia, A. Matarrese and G. Piscitelli. - 1993. Observations on population biology of the blackmouth catshark Galeus melastomus (Chondrichthyes, Scyliorhinidae) in the Ionian Sea. Cybium, 17: 187-196.

Whittaker, R.H. - 1956. Vegetation of the Great Smoky Mountains. Ecol. Monogr., 26(1): 1-69.

Scient. ed.: D. Vaqué.

Guest ed.: G. Morey.

Received February 10, 2010. Accepted March 24, 2011.

Published online August 22, 2011.

This is a contribution to 13th European Elasmobranch Association Conference (Palma, 19-22 November 2009). 